\title{
Pre-existing Corneal Astigmatism in patients undergoing Cataract Surgery in Western Nepal; A hospital-based Unicentered, Comprehensive, Prospective Observational Study
}

\author{
Shrestha S, Kaini KR
}

Department of Ophthalmology, Manipal Teaching Hospital, Pokhara, Nepal

Received: August 15, 2020

Accepted: December 25, 2020

Published: December 30, 2020

Cite this paper:

Shrestha S, Kaini KR. Pre-existing Corneal Astigmatism in patients undergoing Cataract Surgery in Western Nepal; A hospital-based Unicentered, Comprehensive, Prospective Observational Study. Nepal Journal of Medical Sciences 2020;5(2):21-25. http://dx.doi.org/10.3126/njms.v5i1.36707

\begin{abstract}
Introduction: Cataract surgery is one of the most commonly performed surgical procedures worldwide. The final postoperative visual acuity is dependent on the pre-existing corneal astigmatism, accurate biometry and surgically induced astigmatism. Because of the increase in the patient's demand for better postoperative visual acuity, it becomes important to evaluate the distribution of pre-existing corneal astigmatism in different populations. The objective of the study was to analyze the magnitude and pattern of pre-existing corneal astigmatism in cataract surgery patients in Western Nepal.
\end{abstract}

Methods: A hospital-based cross-sectional descriptive study was carried out in the Department of Ophthalmology, Manipal Teaching Hospital, Pokhara. Three hundred and two patients undergoing routine cataract surgery between February 2016 and January 2018 were recruited in the study. Keratometric data from these patients were collected and were analyzed using the statistical software SPSS version 21.

Results: The mean age of the subjects was $70.25 \pm 10.97$ years (range 35 to 94 years). There was a preponderance of females (62\%) over males (38\%). The mean corneal astigmatism was $0.78 \pm$ $0.59 \mathrm{D}$ (range 0.00 to $5.00 \mathrm{D}$ ). The pre-existing corneal cylinder $\geq 1.00 \mathrm{D}$ was seen in $40.06 \%$ of patients. The corneal astigmatism was mainly against the rule (65.56\%). The amount of corneal astigmatism and corneal steepness increased with age.

Conclusion: Corneal astigmatism of $1.00 \mathrm{D}$ or more was seen in $40.06 \%$ of the patients undergoing cataract surgery which should be corrected to meet the patient's expectation for good, unaided visual acuity after cataract surgery.

Keywords: Astigmatism; Cataract; Corneal; Surgery

Correspondence to: Dr. Shristi Shrestha

Department of Ophthalmology

Manipal Teaching Hospital, Pokhara, Nepal

Email: shristi495@gmail.com

\section{INTRODUCTION}

Cataract surgery is one of the most commonly performed surgical procedures worldwide. (C) $\begin{aligned} & \text { Licensed under CC BY } 4.0 \text { International License which } \\ & \text { permits use, distribution and reproduction in any } \\ & \text { medium, provided the original work is properly cited }\end{aligned}$ 
The main aim of cataract surgery is rapid visual rehabilitation, the best possible uncorrected visual acuity and minimal postoperative astigmatism. ${ }^{1}$ The final postoperative visual acuity is dependent on the pre-existing corneal astigmatism, accurate biometry, intraocular lens (IOL) power calculation and surgically induced astigmatism. Astigmatism leads to a reduction in visual performance for both distance and near, reduction in stereoacuity and contrast sensitivity. ${ }^{2}$

The prevalence of regular corneal astigmatism in the cataract population has been reported from European nations, China and Thailand. $3,4,5,6,7,8,9$ Similarly, a study has been reported from Central Nepal but none has been conducted in Western Nepal. ${ }^{10}$

The purpose of this study was to analyze the magnitude and pattern of corneal astigmatism in the Nepalese population who underwent routine cataract surgery.

\section{METHODS}

A hospital-based cross-sectional descriptive study was conducted in the Department of Ophthalmology, Manipal Teaching Hospital, Pokhara from February 2016 to January 2018. Three hundred and two patients undergoing routine cataract surgery were recruited. The sample size was calculated using the formula:

$\mathrm{n}=\underline{\mathrm{Za} / 2 \mathrm{x \sigma}}{ }^{2}(\mathrm{Za} / 2=1.96$, where $\mathrm{Za} / 2$ is the standard variate at $95 \%$ confidence interval,

$\mathrm{E}=0.1$, where $\mathrm{E}$ is the margin of error of $10 \%$, $\sigma=0.8 \mathrm{D}$ of mean corneal astigmatism

$$
\begin{aligned}
& \mathrm{E}=\frac{[1.96 \times 0.8]^{2}}{[0.1]^{2}}, \text { SD was taken from the study. }{ }^{10} \\
& =246 .
\end{aligned}
$$

Preceding the study, ethical approval from the institutional research ethical committee was obtained with ID no. MEMG/IRC/ GA 1296. Inclusion criteria included the presence of cataract and age between 35 and 95 years. Exclusion criteria included irregular astigmatism, corneal disease, previous corneal or intraocular surgery, and history of ocular inflammation. Subjects who had participated gave written consent before enrollment in the study. All the patients had undergone complete ophthalmologic examination including visual acuity, refraction, slit-lamp examination, tonometry, keratometry, ultrasound A-scan and B-scan if required. Keratometric data were collected using Bausch and Lomb keratometer (Appa Samy).

Astigmatism was calculated from the dioptric difference of vertical reading from horizontal reading. With the rule (WTR) astigmatism was considered when steep meridian was at $90^{\circ} \pm 20^{\circ}$. Against the rule (ATR) astigmatism was considered when steep meridian was at $180^{\circ} \pm 20^{\circ}$. Astigmatism in another direction was defined as oblique astigmatism.

Data were collected and analyzed using statistical software SPSS version 21.

\section{RESULTS}

During the study period, 302 patients were recruited. The mean age of the subjects was $70.25 \pm 10.97$ years (range was between 35 to 94 years). There was a preponderance of females (62\%) over males (38\%). Table 1 lists the demographic characteristics of the patients. The mean corneal astigmatism was $0.78 \pm 0.59 \mathrm{D}$ (range 0.00 to $5.00 \mathrm{D}$ ).

\section{Table 1: Demographic characteristics and} clinical findings of the study population

\section{Characteristics \\ Value}

$\begin{array}{lc}\begin{array}{l}\text { No. of eyes/patients (n) } \\ \text { Age (years) }\end{array} & 302 / 302 \\ \quad \text { Mean } \pm \text { SD } & 70.25 \pm 10.97 \\ \quad \text { Range } & 35-94 \\ \text { Gender (Male/Female) } & 115 / 187 \\ \text { Mean corneal astigmatism } & 0.78 \pm 0.59 \\ \text { (D) } \pm \text { SD } & 0.00-5.00 \\ \text { Range of corneal astigma- } & \\ \text { tism (D) } & 0.00-5.00 \\ \text { Mean Keratometry (D) } & \\ \quad \text { Flat } \pm \text { SD } & 43.85 \pm 1.31 \\ \quad \text { Steep } \pm \text { SD } & 44.63 \pm 1.44 \\ \text { Range of keratometry (D) } & 40.25-50.00\end{array}$


SD-Standard Deviation, D-Dioptre

Table 2 demonstrates the prevalence of corneal astigmatism stratified by the amount of astigmatism. The pre-existing corneal cylinder $\geq 1.00 \mathrm{D}$ was seen in $40.06 \%$ of patients.

Table 2: Prevalence of corneal astigmatism

\begin{tabular}{lll}
\multicolumn{1}{c}{$\begin{array}{c}\text { Corneal } \\
\text { astigmatism }(\mathrm{D})\end{array}$} & $\begin{array}{c}\text { Frequency } \\
(\mathrm{n})\end{array}$ & $\begin{array}{c}\text { Percentage } \\
(\%)\end{array}$ \\
$<0.5$ & 68 & 22.52 \\
$0.5-<1.0$ & 113 & 37.42 \\
$1.0-<2.0$ & 113 & 37.42 \\
$2.0-<3.0$ & 5 & 1.65 \\
$\geq 3.0$ & 3 & 0.99 \\
TOTAL & 302 & 100 \\
\hline
\end{tabular}

D-Diopter

The corneal astigmatism was mainly against-the-rule (ATR) that was seen in $65.56 \%$, whereas $23.18 \%$ had with-the-rule astigmatism (WTR) as shown in table 3.

Table 3: Pattern of corneal astigmatism

$\begin{array}{llll}\text { Age (Years) } & \text { WTR } & \text { ATR } & \text { N/A } \\ \leq 49 & 8 / 73 \% & 2 / 18 \% & 1 / 9 \% \\ 50-59 & 15 / 43 \% & 13 / 37 \% & 7 / 20 \% \\ 60-69 & 34 / 39 \% & 38 / 43 \% & 16 / 18 \% \\ 70-79 & 12 / 12 \% & 78 / 80 \% & 8 / 8 \% \\ 80-89 & 1 / 2 \% & 62 / 95 \% & 2 / 3 \% \\ \geq 90 & 0 & 5 / 100 \% & 0\end{array}$

WTR- With-the rule-astigmatism, ATR- against-therule astigmatism, NA- No astigmatism

The descriptive statistics by age group are displayed in table 4.

Table 4: Descriptive statistics by age group

$\begin{array}{llccc}\begin{array}{c}\text { Age } \\ \text { (years) }\end{array} & \begin{array}{c}\text { Frequency } \\ (\mathrm{n})\end{array} & \begin{array}{c}\text { Astigmatism } \\ \text { Mean } \pm S D(\mathrm{D})\end{array} & \begin{array}{c}\mathrm{K}^{*} \\ \text { Mean } \pm \mathrm{SD}(\mathrm{D})\end{array} & \begin{array}{c}\mathrm{K} 2^{*} \\ \text { Mean } \pm S D(D)\end{array} \\ \leq 49 & 11 & 0.39 \pm 0.26 & 42.93 \pm 0.35 & 43.32 \pm 0.25 \\ 50-59 & 35 & 0.51 \pm 0.40 & 43.10 \pm 1.17 & 43.59 \pm 1.22 \\ 60-69 & 88 & 0.69 \pm 0.73 & 43.48 \pm 1.34 & 44.18 \pm 1.45 \\ 70-79 & 98 & 0.75 \pm 0.46 & 43.88 \pm 1.18 & 44.63 \pm 1.15 \\ 80-89 & 65 & 1.11 \pm 0.53 & 44.74 \pm 1.04 & 45.85 \pm 0.99 \\ \geq 90 & 5 & 1.55 \pm 0.45 & 45.40 \pm 0.52 & 46.8 \pm 0.59\end{array}$

SD-Standard Deviation, $\quad$ D-Dioptre, ${ }^{\star}$ K1-flat keratometry, K2-steep keratometry

Overall, the maximum number of patients with corneal astigmatism was seen in the age group between 70 to 79 years. There was a progressive increase in the magnitude of astigmatism and both the keratometric values with an increase in age. Figure 1 depicts a progressive increase in ATR astigmatism with age.



Figure 1: Distribution of astigmatism according to various age-groups

\section{DISCUSSION}

The significant visual and functional impact of uncorrected astigmatism emphasizes the need for its correction. The reduction in distance visual acuity with induced astigmatism is said to be least with induced with-the-rule astigmatism and greatest with either againstthe-rule or oblique astigmatism. ${ }^{2}$ Guo and Atchison concluded that a reduction in the visual acuity of $0.1 \log$ MAR line of letters required $0.28 \pm 0.12 \mathrm{D}$ of induced cylindrical power. ${ }^{11}$ So, it is important to analyze the magnitude and pattern of preoperative astigmatism to meet the patient's expectation for good, unaided visual acuity after cataract surgery.

This study reports the burden of corneal astigmatism in patients before cataract surgery and describes the distribution in different age subsets. A significant number of patients undergoing cataract surgery had pre-existing corneal astigmatism of 1.00 $\mathrm{D}$ or more $(40.06 \%)$. These results agree with those seen in Chinese (41\%), and the British population (40.4\%)., ${ }^{5,6}$ The corneal astigmatism was reported to be even higher in another Chinese study (45.4\%) whereas it was less in the Thai population $(37.8 \%)$ and Spanish population (35\%). ${ }^{7,94}$ In the present study, there was a preponderance of females $(62 \%)$ over males (38\%) which was also seen in other studies. ${ }^{4,5,6,7,9}$ This explains that cataract is more prevalent in the female population. 
The mean corneal astigmatism $(0.78 \pm 0.59$ D) was similar to the study by Chaudhary et al. $^{10}(0.84 \pm 0.80 \mathrm{D})$ which was lesser than other studies, which could be due to racial factors. ${ }^{4,5,6,79}$ The range of corneal astigmatism was similar to studies reported by Lekhanont et al. ${ }^{9}(4.5 \mathrm{D})$ and Guan et al. ${ }^{7}(5.2 \mathrm{D})$ and it ranged upto $6.75 \mathrm{D}$ in the Spanish population. ${ }^{4}$ The tendency of corneal astigmatism to increase with age was congruent with several other studies. ${ }^{6,7,89}$ The corneal astigmatism was mainly ATR which was observed in $65.56 \%$ of the subjects. Studies in the Thai population $(62.2 \%)$ and various studies in the Chinese population $(58.2 \%, 53.2 \%, 50 \%)$ resembled our result. ${ }^{6,78,9}$ Rashid et al. ${ }^{12}$ reported a much higher prevalence of ATR (79\%). However, WTR astigmatism was more common among the Germans (46.8\%). ${ }^{3}$ The incidence of ATR astigmatism increased with age. Identical results have been reported by other studies. ${ }^{6,7,9,12}$ The lower range of keratometry values was higher as compared to other studies 40.25 to $50.00 \mathrm{D}$ vs 38.00 to $49.00 \mathrm{D}$ reported by Lekhanont et al. ${ }^{9}$ and 38.00 to $48.00 \mathrm{D}$ by Ferrer-Blasco et al. ${ }^{4}$ The highest range was seen in the study reported by Guan et al. ${ }^{7}$ This study was limited by a small number of subjects. So, it may not represent the data of the whole population of Western Nepal.

\section{CONCLUSION}

The level of corneal astigmatism $\geq 1.00 \mathrm{D}$ was seen in more than one third of the total subjects and majority of them had againstthe-rule astigmatism accounting for twothird of the cases. This amount of corneal astigmatism after the cataract surgery will significantly influence the postoperative visual acuity. Because of the increase in the patient's demand for better postoperative visual acuity, it becomes important to evaluate the distribution of pre-existing corneal astigmatism in different populations.

\section{CONFLICT OF INTEREST}

None

\section{SOURCES OF FUNDING}

None

\section{REFERENCES}

1. Rainer G, Menapace R, Vass C, Annen D, Findl O, Schmetterer K. Corneal shape changes after temporal and superolateral $3.0 \mathrm{~mm}$ clear corneal incisions. $J$ Cataract Refract Surg. 1999;25(8):1121-6. https:// doi.org/10.1016/S0886-3350(99)001327

2. Read SA, Vincent SJ, Collins MJ. The visual and functional impacts of astigmatism and its clinical managements. Ophthalmic Physiol Opt. 2014;34:1-27. https://doi.org/10.1111/opo.12128

3. Hoffman PC, Hutz WW. Analysis of biometry and prevalence data for corneal astigmatism in 23,239 eyes. $J$ Cataract Refract Surg. 2010;36:1479-85. https:// doi.org/10.1016/j.jcrs.2010.02.025

4. Ferrer-Blasco T, Montés-Mico R, Peixoto-de-Malos SC, GonzálezMéijome JM, Cerviño A. Prevalence of corneal astigmatism before cataract surgery. $J$ Cataract Refract Surg. 2009;35(1):70-5. https://doi. org/10.1016/j.jcrs.2008.09.027

5. Khan MI, Muhtaseb M. Prevalence of corneal astigmatism in patients having routine cataract surgery at a teaching hospital in the United Kingdom. $J$ Cataract Refract Surg. 2011;37(10):1751-5. https://doi. org/10.1016/j.jcrs.2011.04.026

6. Chen W, Zuo C, Chen C, Su J, Luo L, Congdon $\mathrm{N}$ et al. Prevalence of corneal astigmatism before cataract surgery in Chinese patients. $J$ Cataract Refract Surg. 2013;39(2):188-92. https://doi. org/10.1016/j.jcrs.2012.08.060

7. Guan Z, Yuan F, Yuan Y, Niu WR. Analysis of corneal astigmatism in cataract surgery candidates at a teaching hospital in Shanghai, China. $J$ Cataract Refract Surgery. 2012;38(11):1970-7. https://doi. org/10.1016/j.jcrs.2012.07.025

8. Cui Y, Meng Q, Guo H, Zeng J, Zhang $\mathrm{H}$, Zhang $\mathrm{G}$ et al. Biometry and corneal astigmatism in cataract surgery candidates 
from Southern China. J Cataract Refract Surgery. 2014;40(10):1661-9. https://doi. org/10.1016/j.jcrs.2014.01.039

9. Lekhanont K, Wuthisiri W, Chatchaipun P, Vongthongsri A. Prevalence of corneal astigmatism in cataract surgery candidates in Bangkok, Thailand. $J$ Cataract Refract Surg. 2011;37:613-5. https://doi. org/10.1016/j.jcrs.2010.12.038

10. Chaudhary M, Dahal HN. Prevalence and types of corneal astigmatism in patients undergoing cataract surgery. Journal of Institute of Medicine. 2017;39(1):22-28. Available from: https://www.researchgate.net/ publication/319903534_Prevalence and types of corneal astigmatism in patients undergoing_cataract surgery 1 [Accessed 20th November 2020]

11. Guo H, Atchison DA. Subjective blur limits for cylinder. Optom Vis Sci. 2010;87(8):E549-59. https://doi. org/10.1097/OPX.0b013e3181e61b8f

12. Rashid MA, Hossain KA, Islam AKMR. Prevalence of pre-existing corneal astigmatism in age-related cataract patients. Faridpur Med Coll J. 2013;8(1):02-04. https://doi.org/10.3329/ fmcj.v8i1.16887 